\title{
Activity of Some Brazilian Isolates of Entomopathogenic Fungi Against the Poultry Red Mite Dermanyssus Gallinae De Geer (Acari: Dermanyssidae)
}

\section{-Author(s)}

\section{Kasburg CR' \\ Alves LFA" \\ Oliveira DGPIII \\ Rohde CIV}

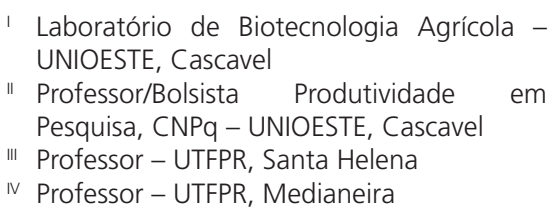

\section{Mail Address}

Corresponding author e-mail address Luis Francisco Angeli Alves

Laboratório de Biotecnologia Agrícola UNIOESTE, Rua Universitária, 2069

85819-110. Cascavel, PR, Brasil

Tel: $\quad$ (005545) 32203288

Email: luis.alves@unioeste.br

\section{-Keywords}

Hematophagous mites, microbial control, ectoparasites, laying hens.

\section{ABSTRACT}

Poultry red mite Dermanyssus gallinae is a cosmopolitan and hematophagous species commonly found in layer houses around the world. Poultry mite infestations may cause anemia, stress, low body weight and egg production, and mortality. Mite control is typically based on chemical products, but they are not effective and leave residues in eggs; therefore, alternative control methods, such as entomopathogenic fungi, need to researched. This study aimed at evaluating, in the laboratory, the activity of Brazilian isolates of entomopathogenic fungi against $D$. gallinae. The mites were collected from a commercial layer house and were sprayed with conidial suspensions $\left(1 \times 10^{8}\right.$ conidia/ $\mathrm{mL}$ ) of five isolates of Beauveria bassiana and Metarhizium anisopliae. All tested isolates were pathogenic for the red mite, with confirmed mortality ranging from 22.9 to $52.4 \%$. This demonstrate the potential of the tested entomopathogenic fungi isolates for mite control, and reinforces the need for further studies with other isolates, application strategies, and with fungal formulations.

\section{INTRODUCTION}

Brazilian egg production is based on intensive farming systems, which ensure greater yield in a smaller physical space. However, it favors the development of arthropod pests, such as the red mite Dermanyssus gallinae (De Geer) (Acari, Dermanyssidae). This mite feeds on poultry, causing weight loss, reduced egg production, blood spoliation anemia and, in more severe cases, death. Studies have shown that the red mite can carry Escherichia coli, Salmonella and Coxiella burnetii, as well as viruses (Saint Louis encephalitis virus, avian poxvirus, avian paramyxovirus type I and Newcastle disease virus). In all these cases, the mite may acquire these microorganisms by feeding on the blood of infected birds (Moro et al., 2007; Harrington et al., 2011; Pereira, 2009; 2011; Sparagano et al., 2014).

Mite control in poultry houses is based on chemical acaricides that are apparently effective because they cause momentary reduction of the pest population. Misuse of these products can lead to residues in the eggs, poisoning of workers and poultry in layer houses, environmental contamination; and can also select individuals resistant to the active ingredients (Chauve, 1998; Pereira, 2009; Liebisch, 2011).

As an alternative to chemical control, entomopathogenic fungi Beauveria bassiana (Bals.) Vuill. and Metarhizium anisopliae (Metsch.) Sorok isolates from Europe were evaluated against red mites (Steenberg \& Kilpinen 2003). In addition, studies conducted in the laboratory and in the field in Iran and Egypt confirmed the action of fungal isolates from Europe and Asia against D. gallinae (Steenberg et al., 2006; Kaoud, 2010; Tavassoli et al., 2008; Steenberg \& Kilpinen, 2014). 
However, in Brazil, studies on alternative pest control are focused only in the in-vitro evaluation of plant extracts (Morrone et al., 2001; Soares, 2012; Oliveira et al., 2014). Therefore, the objective of the present study was to evaluate for the first time the pathogenicity of Brazilian isolates of $B$. bassiana and $M$. anisopliae against $D$. gallinae.

\section{MATERIALS AND METHODS}

Mites were collected from a commercial layer house. Engorged mite females were selected based on their description (Flechtmann, 1973), placed in glass tubes closed with gauze, and kept at $26^{\circ} \mathrm{C}, 70 \% \mathrm{RH}$ and $12 \mathrm{~h}$ photoperiod for acclimatization until use in the experiment (Soares, 2012). Isolates of the fungi $B$. bassiana (Unioeste 01, Unioeste 02, Unioeste 04 and Unioeste 05) and Metarhizium anisopliae (Unioeste 22) were evaluated (Table 1).

The fungi were grown in culture medium (sporulation medium) in Petri dishes ( 10 days at $26^{\circ} \mathrm{C}$; $12 \mathrm{~h}$ photoperiod) (Alves et al., 1998). After incubation, conidia were collected by scrapping the surface of the culture medium. A suspension of conidia was prepared $\left(1 \times 10^{8}\right.$ conidia $\left./ \mathrm{mL}\right)$ in distilled water + Tween $80^{\circledR}$ at $0.01 \%$. Fifteen adult female mites were transferred to a Petri dish and sprayed with $1 \mathrm{~mL}$ of the conidial suspension using a Potter spray tower $\left(0.7 \mathrm{kgf} / \mathrm{cm}^{2}\right)$. As control treatment, only distilled water + Tween $80^{\circledR}$ to $0.01 \%$ was applied. After spraying, mites were transferred to glass tubes closed with cotton gauze plug, and observed daily for seven days. The dead mites were removed using a fine-tipped brush and placed in a humid chamber and incubated under the abovementioned conditions for the confirmation of mortality by the fungus. All treatments included seven replicates of 15 mites each. Experiments were repeated twice.
A completely randomized experimental design was applied. Total and confirmed mortality data were transformed into arcsen $\sqrt{100}$ and analyzed for normality and variance homogeneity by the Shapiro-Wilk and Levene's tests, respectively. Means were compared by Tukey's test $(p \leq 0.05)$ using Sisvar statistical software (Ferreira, 2011).

\section{RESULTS AND DISCUSSION}

All $B$. bassiana isolates were pathogenic for the poultry red mite $D$. gallinae (confirmed mortality between 22.9 and 52.4\%). Significant differences were detected only between Unioeste 2 and Unioeste 4 isolates. The $M$. anisopliae Unioeste 22 isolate caused $52.4 \%$ total mortality and only $38.1 \%$ confirmed mortality (Table 1).

Steenberg \& Kilpinen (2003) also found 60\% mortality of the poultry red mite by $B$. bassiana and $30 \%$ by $M$. anisopliae in the laboratory. The acaricidal activity of a commercial product based on of $B$. bassiana conidia in a powder formulation was also demonstrated under laboratory conditions, with $65 \%$ mortality after five days of inoculation (Kaoud, 2010).

Isolates of $M$. anisopliae were also pathogenic against mite $D$. gallinae in the laboratory, with mortality ranging between 40 and $70 \%$ depending on the tested isolates, and, under field conditions, they were shown to be efficient in commercial poultry houses treated with a conidia suspension at a high concentration $(1 \times$ $10^{9}$ conidia/mL) (Tavassoli et al., 2008, 2011).

The results of the present study demonstrate the potential of the tested entomopathogenic fungi isolates for the control of the poultry red mite. However, it should be noted that this is a preliminary test with Brazilian isolates, and further research is suggested to find more virulent isolates and to test

Table 1 - Total and confirmed mortality of D. gallinae by different isolates of entomopathogenic fungi.

\begin{tabular}{lccc}
\hline Treatment & \multicolumn{1}{c}{ Host $^{1}$} & Total mortality & Confirmed mortality \\
\hline Control & & $25.7 \pm 1.29 \mathrm{~b}$ & $0.0 \pm 0.00 \mathrm{c}$ \\
\hline Beauveria bassiana & & & \\
Unioeste 01 & Astylus variegatus (adult) & $49.5 \pm 1.75 \mathrm{ab}$ & $43.8 \pm 1.70 \mathrm{ab}$ \\
Unioeste 02 & Alphitobius diaperinus (larvae) & $71.4 \pm 1.22 \mathrm{a}$ & $65.7 \pm 1.14 \mathrm{a}$ \\
Unioeste 04 & Alphitobius diaperinus (larvae) & $37.2 \pm 1.71 \mathrm{ab}$ & $22.9 \pm 1.28 \mathrm{~b}$ \\
Unioeste 05 & Alphitobius diaperinus (adult) & $59.1 \pm 1.10 \mathrm{ab}$ & $52.4 \pm 1.07 \mathrm{ab}$ \\
\hline Metarhizium anisopliae & & & $38.1 \pm 0.56 \mathrm{ab}$ \\
Unioeste 22 & Soil, llex paraguaiensis plantation & $52.4 \pm 0.59 \mathrm{ab}$ & 42.5 \\
\hline CV (\%) & & 36.3 & 3 \\
\hline
\end{tabular}

'Entomopathogenic Fungi Collection - Laboratory of Agricultural Biotechnology, Unioeste-Cascavel, PR, Brazil. Astylus variegatus and Alphitobius diaperinus - Coleoptera: Melyridae and Tenebrionidae, respectively.

Means followed by the same letter incolumn do not differ by Tukey's test $(p \leq 0.05)$ 
Kasburg CR, Alves LFA, Oliveira DGP, Rohde C
Activity of Some Brazilian Isolates of Entomopathogenic Fungi Against the Poultry Red Mite Dermanyssus Gallinae De Geer (Acari: Dermanyssidae) application strategies and fungal formulations, both in the laboratory and in the field.

\section{ACKNOWLEDGEMENTS}

The authors are thankful to the Brazilian National Research Council (CNPq) and to the Coordination for the Improvement of Higher Education Personnel (CAPES) for providing the research grants.

\section{REFERENCES}

Alves SB, Almeida JEM, Moino Jr A, Alves LFA. Técnicas de Laboratório. In: Alves SB, editor. Controle microbiano de insetos. Piracicaba: FEALQ; 1998. p.637-712.

Chauve C. The poultry red mite Dermanyssus gallinae (De Geer 1778): current situation and future prospects for control. Veterinary Parasitology 1998;79:239-245.

Ferreira DF. Sisvar: a computer statistical analysis system. Ciência e Agrotecnologia 2011;35(6):1039-1042.

Flechtmann CHW. Ácaros de importância medico-veterinária. São Paulo: Nobel; 1985. 192p.

Harrington DWJ, George DR, Guy JH, Sparagano OAE. Opportunities for integrated pest management to control the poultry red mite Dermanyssus gallinae. World's Poultry Science Journal 2011;67: 83-93.

Kaoud HA. Susceptibility of poultry red mites to entomopathogens. Internacional Journal of Poultry Science 2010;9(3):259-263.

Liebisch G, Hack R, Smid G. Efficacy of spinosad against the poultry red mite, Dermanyssus gallinae (Mesostigmata: Dermanyssidae), in laboratory and field trials. In: Moraes GJ de, Proctor $\mathrm{H}$, editors. Proceedings of the Acarology $13^{\circ}$ International Congress; 2011; Wellington. Nova Zelândia. p. 282-287.

Moro CV, Chauve C, Zenner L. Experimental infection of Salmonella enteritidis by the poultry red mite, Dermanyssus gallinae. Veterinary Parasitology 2007;146:329-336.

Morrone F, Mayworm MAS, Tucci EC, Salatino A, Guerreiro Filho O. Ação acaricida de extratos foliares de espécies de Coffea (Rubiaceae) sobre
Dermanyssus gallinae (De Geer, 1778) (Acari: Dermanyssidae). Arquivos do Instituto Biológico 2001;68(2):43-47.

Oliveira DGP, Alves LFA, Sosa-Gómez DR. Advances and perspectives of the use of the entomopathogenic fungi Beauveria bassiana and Metarhizium anisopliae for the control of arthropod pests in poultry production. Brazilian Journal Poultry Science 2014;16(1):1-12.

Pereira MC. Ectoparasitose. In: Revolledo L, Ferreira AJP, editors. Patologia aviária. Barueri; 2009. p.322-327.

Pereira DMC. Dermanyssus gallinae em galinhas poedeiras em bateria: carga parasitária, ação vectorial e ensaio de campo de um biopesticida [dissertation]. Lisboa: Universidade Técnica de Lisboa; 2011.

Soares LB. A constituição química do óleo essencial de folhas, atividade fungicida e acaricida de Artemisia vulgaris L. e potencial aplicação na avicultura industrial [dissertation]. São Paulo(SP): Instituto Biológico; 2012

Sparagano OAE, George DR, Harrington DWJ, Giangaspero A. Significance and control of the poultry red mite, Dermanyssus gallinae. Annual Review Entomology 2014;59:447-466

Steenberg T, Kilpinen O. Fungus infection of the chicken mite Dermanyssus gallinae. Insect pathogens and insect parasitic nematodes 2003, Dinamarca. IOBC WPRS Bulletin 2003;26(1):23-25.

Steenberg T, Kilpinen O, Moore D. Fungi for control of the poultry red mite, Dermanyssus gallinae. Proceedings of the International Workshop "Implementation of Biocontrol in Practice in Temperate Regions Present and Near Future"; 2005 Nov 1-3; Denmark, Copenhague. p.71-73.

Steenberg T, Kilpinen O. Synergistic interaction between the fungus Beauveria bassiana and desiccant dusts applied against poultry red mites (Dermanyssus gallinae). Experimental \& Applied Acarology 2014;62:511-524

Tavassoli M, Ownag A, Pourseyed SH, Mardani K. Laboratory evaluation of three strains of the entomopathogenic fungus Metarhizium anisopliae for controlling Dermanyssus gallinae. Avian Patology 2008;37(3):259263.

Tavassoli M, Allymehr M, Pourseyed SH, Ownag A, Bernousi I, Mardani $\mathrm{K}$, et al. Field bioassay of Metarhizium anisopliae strains to control the poultry red mite Dermanyssus gallinae. Veterinary Parasitology 2011;178:374 378 
